\title{
AUTHENTIC LEADERSHIP BEHAVIOR IN PUBLIC MIDDLE SCHOOL
}

\author{
Johansyah ${ }^{\text {a* }}$ \\ $\mathrm{a}^{*}$ Universitas Mulawarman Samarinda \\ Jl. Kuaro - Tanah Grogot, , Kalimantan Timur, Indonesia. syamjohansyah@gmail.com
}

\begin{abstract}
This study aims to determine the effect of managerial competence and cooperation of school principals on the job satisfaction of educators in state junior high schools. This research uses quantitative and descriptive approaches. In terms of this type of research is a type of correlational research that is research that seeks to connect two or more variables based on facts that have occurred through data collection, data processing, then analyzing and finally explaining according to facts. The population of this study was all school principals and state junior high school teachers in East Borneo (South Balikpapan and East Kutai). The sampling technique uses this purposive sampling technique by taking schools in the Municipality of Balikpapan and East Kutai with a total of 20 teachers. The results of this study indicate that there is a positive and significant correlation between the managerial skills of school principals ((X1) and the satisfaction of teachers (Y) of SMP in East Borneo with a partial correlation coefficient of 0.450. then known that there is a significant correlation between the cooperation of principals (X2) on the satisfaction of teaching staff (Y) SMP in East Borneo with a partial correlation coefficient of 0.209. and there is a significant influence between the managerial skills of principals (X1) and collaboration of principals (X2) on the satisfaction of educators (Y) Middle East Borneo Middle Schools with a multiple correlation coefficient (Multiple R) of 0.440 which means that the managerial skills of principals ((X1) and the cooperation of school principals (X2) towards the satisfaction of educators (Y) is $44.0 \%$ so that the high and low level of managerial skills in school principals, and the cooperation of school principals will determine the satisfaction of teacher performance.
\end{abstract}

Keywords: cooperation of school principals, managerial ability, satisfaction of educators.

Received: 24 Oct 2019 - Revised: 28 Nov 2019 - Accepted 21 Dec 2019 - Available online 30 Dec 2019

\section{INTRODUCTION}

An overview of the evolution of school

Implementation of Minister of Education Regulation no. 13 of 2007 concerning the competency standards of principals set dimensions of principals' competencies including personality, managerial, entrepreneurship, supervision and social competencies. The level of the principal's ability to direct, empower, mobilize and develop school resources in improving the quality of education at school depends on the competency of the principal's managerial principal. Ministry of National Education
(2007), outlines that the school principal is an educator who gets an additional assignment. The task of a school principal is crucial in improving the quality of education at the school. A principal, in addition to being able to carry out management processes that refer to management functions, is also required to understand and apply the whole substance of educational activities.

Sanusi in Rais (2014: 2) states that, changes in the role and function of schools from static in the past to the dynamic and functional constructive in the era of globalization, bringing school responsibilities to the broader. 


\section{Johansyah / Journal of Educational Administration Research and Review / \\ Vol. 3 No. 2 December 2019}

One of the functions of the principal of the school as an educational administrator needs to equip his educational leadership insight with knowledge and attitude that is anticipative of changes that occur in community life, including the development of macro education policies.

In the perspective of improving the quality of education there are four abilities that must be possessed by an educational leader, namely:

(1) The ability to organize and assist staff in formulating improvements in education in schools in the form of a complete program;

(2) The ability to generate and foster confidence in yourself from educators and other school staff members;

(3) The ability to foster and foster cooperation in promoting and implementing supervision programs; and

(4) The ability to encourage and guide educators and all other school staff so that they are willing and responsible to actively participate in every school's efforts to achieve the school's goals as best they can.

One of the prepositions on education policy for school principals, that the minimum competency of a school principal is to have knowledge and skills in the field of school administration, human relations skills with student and community staff, and instructional and non-instructional technical skills.

According to Katz and Payol (Robbins, 2003) that in the framework of carrying out managerial tasks, a minimum of three types of skills are required, namely technical skills, human skills, conceptual skills.

(1) Technical skills, namely skills related to certain knowledge, methods, and techniques in completing certain tasks;

(2) Human skills are skills that show the ability of a manager to work efficiently with others;
(3) Conceptual skills are skills relating to the way the headmaster views the school, the relationship between the school and the structure above it and with social institutions, and the overall school work program.

The principal is the person who is responsible for fostering cooperation in the school. A pleasant atmosphere of cooperation in schools will occur if the principal, teachers, administrative staff and students have an agreement in achieving educational goals at school. Disagreement between these elements will lead to conflict in the school. This of course will hamper efforts to achieve educational goals. For this reason, school principals must try to avoid conflicts in the school. Thus the role of the principal is very important in helping to realize job satisfaction with teachers at the school.

Based on the problem limitation that is the focus of the study, the formulation of the problem can be described as follows:

1. Is there an influence between principals managerial competence on the job satisfaction of educators in East Borneo Middle Schools?

2. Is there an influence between the cooperation of school principals on the job satisfaction of educators in Public Middle Schools in East Borneo?

3. Is there an influence of the principal's managerial competence and collaboration on the job satisfaction of educators in state junior high schools in East Borneo?

\section{METHODS}

The approach used in this study is a quantitative and descriptive approach that tries to prove the hypothesis by statistical analysis that is explained as is. In terms of this type of research is a type of correlational research that is research that seeks to connect two or more variables based on facts that have occurred through data collection, data processing, then analyzing and finally explaining according to facts.

Authentic Leadership Behavior in Public Middle School | 129 


\section{Johansyah / Journal of Educational Administration Research and Review / \\ Vol. 3 No. 2 December 2019}

The population of this study was all school principals and state junior high school teachers in East Borneo (South Balikpapan and East Kutai). The sampling of this research is using purposive sampling technique, which is one of the non-random sampling techniques, where the researcher determines the sampling by specifying specific characteristics that fit the research objectives so that it is expected to answer the research problem. Purposive Sampling is by taking schools in the Municipality of Balikpapan and East Kutai.

The instrument testing was conducted on 20 teachers. Testing the validity and reliability is done by comparing the correlation value ( $\mathrm{r}$ count) of each statement with a critical value of $\mathrm{r}$ ( $\mathrm{r}$ table) at $\mathrm{df}=18$ with a $95 \%$ confidence level of 0.468 .

Data analysis techniques in this study used simple correlation analysis techniques and multiple regression analysis (multiple regression analysis) with the help of the program SPSS 24.00.

\section{RESULTS AND DISCUSSION}

This research was conducted on junior high school educators in East Borneo with a sample of 71 people. The research data was taken using a questionnaire that has been tested for validity and reliability for each variable, namely the variable School Managerial Skills $\left(\mathrm{X}_{1}\right)$, School Principal Cooperation $\left(\mathrm{X}_{2}\right)$, and Workforce Satisfaction of Educators (Y) with the following data description:

Respondents' answers about the managerial skills of junior high school principals in East Borneo were 30 questions including Conceptual Skill, Human Skill, and Technical Skill indicators with a maximum score of 140 and a minimum score of 105 with an average score of 121.35 and a standard deviation (s) of 8,889 . From this range of data, five criteria are then made namely managerial skills are very good, good, good enough, not good, and managerial skills are not good. It turns out that in general according to the opinion of respondents managerial skills are good, for more details can be seen in the following table:

Table 4.1 Opinion of Respondents on Managerial Skills of Middle School Principals in East Borneo

\begin{tabular}{ccccc}
\hline No & Criteria & Score & Frequency & Presentase (\%) \\
\hline 1 & Very good & $61-65$ & 3 & 4.22 \\
2 & Good & $56-60$ & 17 & 23.94 \\
3 & Enough & $51-55$ & 24 & 33.80 \\
4 & Bad & $46-50$ & 20 & 28.16 \\
5 & Very Bad & $41-45$ & 7 & 9.86 \\
\hline & & 71 & 100 \\
\hline
\end{tabular}

The results of the study for each item based on sub-variables are as follows:

1. Conceptual Skill

Principals who have good managerial skills one of the indicators is having concept skills. These concept skills include the skills to plan all school activities, diagnose school problems, solve problems, coordinate school activities, develop curriculum, develop staff to achieve school goals.

Based on the results of the study, the perception of educators about the concept of leadership owned by the head, namely:

Table. 4.2 Respondents' Opinions About Concept Skills

\begin{tabular}{ccccc}
\hline No & Criteria & Score & Frequency & $\begin{array}{c}\text { Presentase } \\
(\%)\end{array}$ \\
\hline 1 & Very good & $61-65$ & 3 & 4.22 \\
2 & Good & $56-60$ & 17 & 23.94 \\
3 & Enough & $51-55$ & 24 & 33.80 \\
4 & Bad & $46-50$ & 20 & 28.16 \\
5 & Very Bad & $41-45$ & 7 & 9.86 \\
\hline & Sum & & 71 & 100 \\
\hline
\end{tabular}

2. Human Skill

The results of the study found that the human relations skills possessed by the principals of SMPs in East Borneo were:

Table 4.3 Respondents' opinions on Human Relations Skills

\begin{tabular}{|c|c|c|c|c|}
\hline No & Criteria & Score & Frequency & $\begin{array}{c}\text { Presentase } \\
(\%)\end{array}$ \\
\hline
\end{tabular}




\begin{tabular}{ccccc}
\hline 1 & Very good & $48-51$ & 6 & 8.45 \\
2 & Good & $44-47$ & 25 & 35.21 \\
3 & Enough & $40-43$ & 16 & 22.53 \\
4 & Bad & $36-39$ & 16 & 22.53 \\
5 & Very Bad & $32-35$ & 8 & 11.26 \\
\hline & Sum & 71 & 100 \\
\hline
\end{tabular}

\section{Technical Skill}

The results of the study concluded that the technical skills possessed by junior high school principals in East Borneo were:

Table 4.4 Respondents' Opinions About Technical Skills

\begin{tabular}{ccccc}
\hline No & Criteria & Score & Frequency & $\begin{array}{c}\text { Presentase } \\
(\%)\end{array}$ \\
\hline 1 & Very good & $33-35$ & 9 & 12.67 \\
2 & Good & $30-32$ & 10 & 14.08 \\
3 & Enough & $27-29$ & 39 & 54.92 \\
4 & Bad & $24-26$ & 10 & 14.08 \\
5 & Very Bad & $21-23$ & 3 & 4.22 \\
\hline & Sum & 71 & 100 \\
\hline
\end{tabular}

Questionnaire on the cooperation of SMP schools in East Borneo totaling 38 statements that included indicators of openness in carrying out tasks, intimacy between individuals, respecting opinions and work of others and acceptance of joint decisions obtained a maximum score of 163 and a minimum of 116 , with an average score 139.85 and standard deviation (s) 7.50. from the data range, then five criteria are established namely the cooperation of the principal is very good, good, quite good, not good and not good. From the respondents' answers in general the cooperation between the principals of SMPs in East Borneo was quite good. For more details can be seen in the following table:

Table 4.5 Respondents Opinions About the Cooperation of Middle School Principals in East Borneo

\begin{tabular}{ccccc}
\hline No & Criteria & Score & Frequency & $\begin{array}{c}\text { Presentase } \\
(\%)\end{array}$ \\
\hline 1 & Very good & $160-181$ & 9 & 12.67 \\
2 & Good & $138-159$ & 36 & 50.70 \\
3 & Enough & $116-137$ & 22 & 30.98 \\
4 & Bad & $94-115$ & 3 & 4.22 \\
5 & Very Bad & $72-93$ & 1 & 1.40 \\
\hline & Sum & & 71 & 100 \\
\hline
\end{tabular}

The condition of the principal's cooperation based on the existing sub-variables is as follows:

1. Openness in Performing Tasks The results of the study carried out obtained the following results:

Table 4.6 Respondents' Opinions About Openness in Performing Tasks

\begin{tabular}{ccccc}
\hline No & Criteria & Score & Frequency & $\begin{array}{c}\text { Presentase } \\
(\%)\end{array}$ \\
\hline 1 & Very good & $45-50$ & 11 & 15.49 \\
2 & Good & $39-44$ & 25 & 35.21 \\
3 & Enough & $33-38$ & 24 & 33.80 \\
4 & Bad & $27-32$ & 10 & 14.08 \\
5 & Very Bad & $21-26$ & 1 & 1.40 \\
\hline \multicolumn{2}{r}{ Sum } & 71 & 100 \\
\hline
\end{tabular}

2. Familiarity Between Personal Relations The results of research on Middle East Middle School teaching staff can be seen in the following table:

Table 4.7 Respondents' Opinions About Inter-Personal Familiarity

\begin{tabular}{ccccc}
\hline No & Criteria & Score & Frequency & $\begin{array}{c}\text { Presentase } \\
(\%)\end{array}$ \\
\hline 1 & Very good & $45-50$ & 11 & 15.49 \\
2 & Good & $39-44$ & 25 & 35.21 \\
3 & Enough & $33-38$ & 24 & 33.80 \\
4 & Bad & $27-32$ & 10 & 14.08 \\
5 & Very Bad & $21-26$ & 1 & 1.40 \\
\hline & Sum & 71 & 100 \\
\hline
\end{tabular}

3. Respect the Opinions and Work of Others The results of a study of junior high school educators in East Borneo can be seen in the following table:

Table 4.8 Respondents' Opinions About Appreciating the Opinions and Work of Others

\begin{tabular}{ccccc}
\hline No & Criteria & Score & Frequency & $\begin{array}{c}\text { Presentase } \\
(\%)\end{array}$ \\
\hline 1 & Very good & $47-52$ & 17 & 23.94 \\
2 & Good & $41-46$ & 24 & 33.80 \\
3 & Enough & $35-40$ & 21 & 29.57 \\
4 & Bad & $29-34$ & 8 & 11.26 \\
5 & Very Bad & $22-28$ & 1 & 1.40 \\
\hline & Sum & 71 & 100 \\
\hline
\end{tabular}

4. Acceptance of Joint Decisions

Acceptance of joint decisions is the attitude of the teaching staff that must be undertaken in accepting a joint decision in the collaboration of the principal. A 


\section{Johansyah / Journal of Educational Administration Research and Review / \\ Vol. 3 No. 2 December 2019}

summary of the research results is in the table below:

Table 4.9 Respondents' Opinions About Acceptance of Joint Decisions

\begin{tabular}{ccccc}
\hline No & Criteria & Score & Frequency & $\begin{array}{c}\text { Presentase } \\
(\%)\end{array}$ \\
\hline 1 & Very good & $23-26$ & 7 & 9.85 \\
2 & Good & $19-22$ & 23 & 32.39 \\
3 & Enough & $15-18$ & 30 & 42.25 \\
4 & Bad & $11-14$ & 10 & 14.08 \\
5 & Very Bad & $7-10$ & 1 & 1.40 \\
\hline & Sum & 71 & 100 \\
\hline
\end{tabular}

From the questionnaire about the satisfaction of junior high school educators in East Borneo, 27 questions included indicators of recognition of teaching staff, conformity with duties, work itself, opportunities for promotion, decent salary, administration, pattern of relationships, working conditions and job security can be seen in the following table:

Table 4.10 Opinions of Respondents on the Satisfaction of Middle East Educator Teachers

\begin{tabular}{ccccc}
\hline No & Criteria & Score & Frequency & $\begin{array}{c}\text { Presentase } \\
(\%)\end{array}$ \\
\hline 1 & Very good & $129-133$ & 4 & 5.63 \\
2 & Good & $124-128$ & 10 & 14.08 \\
3 & Enough & $119-123$ & 15 & 21.12 \\
4 & Bad & $114-118$ & 24 & 33.80 \\
5 & Very Bad & $109-113$ & 18 & 25.35 \\
\hline \multicolumn{2}{r}{ Sum } & 71 & 100 \\
\hline
\end{tabular}

As for their opinions on indicators of workforce satisfaction, labor is divided into two parts, namely:

1. Motivation Factors

Motivation Factor is the source of job satisfaction of educators that comes more from the teaching staff themselves, including recognition of the task, conformity to the task, the work itself, and promotion opportunities. The results of the study can be seen in the following table:

Table 4.11 Respondents' Opinions about Motivation Factors

\begin{tabular}{ccccc}
\hline No & Criteria & Score & Frequency & $\begin{array}{c}\text { Presentase } \\
(\%)\end{array}$ \\
\hline 1 & Very good & $56-58$ & 0 & 0 \\
2 & Good & $53-55$ & 39 & 54.92 \\
3 & Enough & $50-52$ & 6 & 8.45 \\
4 & Bad & $47-49$ & 13 & 18.30 \\
\hline
\end{tabular}

\begin{tabular}{ccccc}
\hline 5 & Very Bad & $44-46$ & 13 & 18.30 \\
\hline & Sum & & 71 & 100 \\
\hline
\end{tabular}

2. Hygiene Factors

Hygiene factors are indicators of job satisfaction of educators that originate from external situations including salary, an administration that is not burdensome, work relationships, working conditions and job security. The results of the study illustrate that as many as $47.88 \%$ of teaching staff said that they did not get the healthful factors from job satisfaction well which did not encourage them to be satisfied with their work. The complete results of the study are shown in the following table:

Table 4.12 Respondents' Opinions about Healthful Factors

\begin{tabular}{ccccc}
\hline No & Criteria & Score & Frequency & $\begin{array}{c}\text { Presentase } \\
(\%)\end{array}$ \\
\hline 1 & Very good & $77-80$ & 8 & 11.26 \\
2 & Good & $73-76$ & 7 & 9.85 \\
3 & Enough & $69-72$ & 13 & 18.30 \\
4 & Bad & $65-68$ & 34 & 47.88 \\
5 & Very Bad & $61-64$ & 9 & 12.67 \\
\hline & Sum & 71 & 100 \\
\hline
\end{tabular}

As one of the prerequisites for the regression analysis, the distribution of power analyzed must be normal, so the data normality level is tested first using the "KolmogrovSmirnov Goodnessof Fill Test analysis assisted by the statistical data processing computer SPSS (Statistical Program For Social Science) Version 24.00. The summary of the analysis results is shown in the following table:

\begin{tabular}{|c|c|c|c|c|}
\hline Tes & $\begin{array}{c}\text { omoge } \\
\text { Leven } \\
\text { e } \\
\text { Statisti } \\
\text { c } \\
\end{array}$ & of & $\begin{array}{l}\text { nces } \\
\text { df2 }\end{array}$ & Sig. \\
\hline $\begin{array}{c}\text { Principal's } \\
\text { Managerial } \\
\text { Skills } \\
\text { School }\end{array}$ & 1.808 & 13 & 54 & .065 \\
\hline $\begin{array}{c}\text { Principal } \\
\text { Cooperation }\end{array}$ & 1.769 & 13 & 52 & .074 \\
\hline
\end{tabular}

Based on the table above it can be seen that the value of the Levene Test Statistic based on the value of the principal's managerial skills (X1) 


\section{Johansyah / Journal of Educational Administration Research and Review / \\ Vol. 3 No. 2 December 2019}

shows the number 1,808 with a probability of 0.065 , and the cooperation of the principal (X2) shows the number 1,769 with a probability of 0.074. The probability value indicates a number greater than the significance level $\alpha=$ 0.05 so that the data taken from each sample unit with homogeneous variations.

For the previous linear regression analysis, it is necessary to test the linearity of the relationship between the independent and dependent variables, namely X1-Y and X2-Y, namely the relationship between the principal's managerial skills variable (X1) and the satisfaction of educators $(\mathrm{Y})$ the cooperation of the principal (X2) and teacher satisfaction (Y) as well as the principal's managerial skills variable (X1) and school principal collaboration (X2) with teacher satisfaction (Y). Linearity testing using the help of computer software SPSS statistical data processing software obtained the following results:

1) The relationship between the managerial skill of the principal (X1) and the satisfaction of the teaching staff (Y)

The results of simple regression analysis calculations and linearity tests obtained an $F$ value of 0.201 with a probability value of 0.656. Because the $\mathrm{P}$ value is greater than the 0.05 significance level, it can be stated that the relationship between managerial skills (X1) and teacher satisfaction $(\mathrm{Y})$ does not deviate from the linear line equation.

2) Variable relationship between school principal (X2) and teacher satisfaction (Y) The results of calculation of simple regression analysis and linearity test obtained an $\mathrm{F}$ value of 2.691 with a probability of 0.108 . because the $P$ value is greater than the significance level of 0.05 , it can be stated that the relationship X2 to $\mathrm{Y}$ does not deviate from the linear line equation.

3) The relationship between the principal's managerial skills variable (X1), and the cooperation of the principal (X2) with the satisfaction of educators (Y)
The results of simple regression analysis calculations and linearity tests obtained an $\mathrm{F}$ value of 0.023 with a probability of 0.108 . because the $P$ value is greater than the significance level of 0.05 , it can be stated that the relationship X1, X2 with Y does not deviate from the linear line equation.

The managerial skills of the school principal and the cooperation of the school principal are 1,083 below the number 10 so that multicollinearity is not expected. The Durbin Watson value of the principal's managerial skills variable (X1) towards teacher satisfaction (Y) was 0.947. For the real level of $5 \%$ with 71 respondents were $\mathrm{dL}=1,586$ and $\mathrm{dU}=1,643$. This shows that the Durbin Watson value is below the $\mathrm{dU}$ value so it can be concluded that the regression model contains autocorrelation. There is a model of the relationship of school principals (X2) to the satisfaction of educators obtained Durbin Watson's value of 1,073 . at the $5 \%$ level, the value is below $\mathrm{dL}=1.586$ and $\mathrm{dU}=1.643$ so that the relationship is autocorrelated. For the relationship of principals' managerial skills (X1), collaboration of principals (X2), and satisfaction of educators (Y) Durbin Watson's number of 1.087 was obtained above the value of $\mathrm{dL}=1.557$ and $\mathrm{dU}=1673$ hence the relationship was autocorrelated.

The influence of the principal's managerial skills (X1) on teacher satisfaction (Y)

The results of hypothesis testing using partial test with the help of SPSS program version 24.00 obtained a constant $t$ value of 11.599 and t count of 0.364 with a probability (sig) of 0.000 probability value <level of significate $(0.05)$, it can be concluded that the effect of $\mathrm{X} 1$ on $\mathrm{Y}$ is accepted. This shows that partially $\mathrm{Ha}$ which reads that there is an influence of the principal's managerial skills on teacher satisfaction is accepted with the regression equation $\mathrm{Y}^{\wedge}=121.665+0.031 \mathrm{X} 1$.

Its shows an $\mathrm{R}$ Square value of 0.482 which means that the effective contribution of the managerial leadership variable (X1) to teacher 


\section{Johansyah / Journal of Educational Administration Research and Review / \\ Vol. 3 No. 2 December 2019}

satisfaction $(\mathrm{Y})$ is $48.2 \%$, while $51.8 \%$ is caused by other factors.

1) The influence of school principal collaboration (X2) on teacher satisfaction (Y)

The results of testing the hypothesis using a partial test obtained a constant $t$ value of 10,025 and t count 1,708 with a probability value of 0,000 . The probability value <level of significate $(0.05)$ can be concluded that the influence of $\mathrm{X} 2$ on $\mathrm{Y}$ is accepted. This shows that partially $\mathrm{Ha}$ which reads that there is an influence of the principal's cooperation on the satisfaction of educators is accepted by the regression equation $\mathrm{Y}^{\wedge}=$ $141,779+0.173 \mathrm{X} 2$. The effective contribution of the principal collaboration variable (X2) was $42.0 \%$ while $58 \%$ was caused by other factors

2) Influence of principals' managerial skills (X1), collaboration of principals (X2), and teacher satisfaction $(\mathrm{Y})$

The regression coefficient for principals' managerial skills is 0.330 and the cooperation of principals is 0.183 with a constant of 139.265 so the regression equation is $\mathrm{Y}^{\wedge}=139.265+0.330 \mathrm{X} 1+$ $0.183 \times 2$. The numbers in table 4.11 give meaning:

a. There is an effect of $\mathrm{X} 1$ on $\mathrm{Y}$ if $\mathrm{X} 2$ is controlled

This is evidenced by the t value for $\mathrm{X} 1$ of 8,807 which has a significance value of $0,000<0.05$. the strong relationship between the two if not controlled is 0.14 . If $X_{2}$ is controlled then every increase in one score of the principal's managerial skills will be followed by an increase in teacher satisfaction by 0.450 if the other variables are considered constant.

b. There is an effect of $\mathrm{X} 2$ on $\mathrm{Y}$ if $\mathrm{X} 1$ is controlled

This is evidenced by the $\mathrm{t}$ value for $\mathrm{X}_{2}$ of 1,732 having a significance value of $0,000<0.05$ The strength of the relationship between the two if not controlled is 0.204 . if $\mathrm{X} 1$ is controlled then every increase in one score of principal collaboration will be followed by an increase in labor satisfaction by 0.209 if the other variables are considered constant.

F test results obtained Fcount $=1.507$ and sig $=$ 0.000 . Because the significance value $<0.05$, it can be concluded that Ho is rejected and $\mathrm{Ha}$ is accepted which means Ha which reads there is a significant effect simultaneously on the principal's managerial skills and the principal's cooperation on the satisfaction of educators is accepted. Based on the Adjusted R Square value of 0.440 shows that the simultaneous skills of principals and the cooperation of principals have an effect of $44.0 \%$ on the satisfaction of educators and the remaining $56 \%$ is influenced by other factors beyond these two factors.

From the results of research on managerial skills of junior high school principals in East Borneo which include indicators of Conceptual Skills, Human Skills, and Technical Skills in general according to the perception of educators is good. Educators who think that the principal has managerial skills of the principal are very good at $15.50 \% .29 .57 \%$ of those who thought good were good enough, $26.76 \%$ were good enough, $15.50 \%$ were bad and $12.57 \%$ of those who were not good.

From these results the test for each sub variable found that conceptual ability is included in the quite good category with a percentage of $33.80 \%$. Human relations skills as much as $35.21 \%$ say good. A quite large number is also an opinion which states that human relations skills are in the good enough and not good category by $25.53 \%$ approaching the percentage of good answers. The perception of educators as much as $54.92 \%$ said it was good enough for the technical abilities of the principal so that it needed to be improved.

From the results of the study it can be seen that the data about principals who have managerial skills of principals are included in both categories with a percentage of $29.75 \%$. the main drawbacks are the lack of conceptual skills possessed by the principal, where the 
conceptual skills of $33.80 \%$ in the category are quite good. Some things that can be used as an excuse so that the principal is not good enough to have conceptual skills is the weakness of the principal in planning all school activities. Most of the principals in SMPs in East Borneo make plans for their school activities but only a few are able to carry out the program activities properly. This is due to the conceptual ability to plan school activities is still weak. Many school activity plans are arranged not based on real needs in the field but based on habits that have been in force every year for quite a long time. With the development of school-based management, the current management can provide greater autonomy (authority and responsibility) to schools, provide flexibility / flexibility to schools, and encourage direct participation of school members (educators, students, principals, employees) and community (students' parents, community leaders, scientists, business people, etc.) to be able to improve the quality of schools based on national education policies and applicable laws and regulations. With this autonomy, schools can be given the authority and responsibility to make decisions in accordance with the needs, abilities and demands of the school. Principals should be able to more creatively plan school activities by adopting the vision, mission, and goals of the school to be lowered into the program. school activities, so that school programs are truly rational in accordance with the goals to be achieved by the school. With greater autonomy, schools have greater authority and responsibility in managing their schools, so schools are more independent. With its independence, schools are more empowered in developing programs which of course are in accordance with their needs and abilities / potential. Another conceptual weakness that causes principals' managerial skills have not increased is weakness in coordinating school activities. Currently there are a lot of activities at school that are related to activities that are not directly related to the learning process activities. Examples of such activities include the activities of teaching staff organizations, activities of commemorating national education days, sports day activities, religious holidays activities, other national holidays activities, competition activities both educators, principals, and students where these activities are usually go hand in hand. Principal skills are needed in coordinating these activities. School principals must be brave to take firm steps not to participate in these activities if the benefits obtained are not comparable with the teaching time sacrificed by educators for these activities. Some school principals are weak in coordinating these activities so that many educators are burdened by two jobs at once namely teaching work and participating in activities outside of teaching activities. Weak coordination causes many to be sacrificed. Educators can not teach well which results in the low quality of student learning which will ultimately become a burden for the teaching staff itself. The weakness of the next concept is the weakness of the principal in developing the curriculum. Some of the principals that exist today are senior school principals who are nearing retirement. The headmaster is still very attached to the paternalistic tradition to obey the implementation instructions and technical instructions. Until 2004 schools had not been given the opportunity by the government to develop their own curriculum, only in 2006 the school could develop their own curriculum, the principal as the head of the school should respond well to the development of this curriculum, but because the concept skills to develop the curriculum were still weak many of them responded to the development of this curriculum with apathy. This causes educators who want to develop and innovate to feel limited. Some educators even have the skills to develop a better curriculum than the principal. The principal should be cooperative in developing the curriculum. Although the principal's understanding of curriculum development is still weak but with harmonious collaboration the mastery of the concept of curriculum development can be achieved.

Principal's managerial skills that also have a pretty good number, namely human relations skills as much as $25.53 \%$. the weak human relations skills of the principal are mainly due to the lack of communication between the principal and educators. Many educators do not 


\section{Johansyah / Journal of Educational Administration Research and Review / \\ Vol. 3 No. 2 December 2019}

understand the main tasks and functions of the principal so that if the principal does not often communicate with educators there will be a misunderstanding between them. Many educators feel that they are often left out for service by the school principal so that their functions as supervisors and counselors are not optimal, whereas on the other hand the teaching staff really need guidance from the school principal in carrying out his daily tasks. Harmonious communication between the two is absolutely necessary to suppress the misunderstanding. In the end, it is hoped that there will be mutual understanding in carrying out their respective duties. The concern of the principal can be done by giving awards to outstanding teaching staff. Not many school principals like to give awards to educators. Appreciation is not always valued in quantity, giving praise, shoulders, and giving confidence to carry out certain tasks that indirectly help educators to improve their career paths to be done to improve good relations.

\section{School Principal Cooperation}

The results showed that the cooperation of Middle School principals in East Borneo, which included openness in carrying out tasks, familiarity between individuals, respecting the opinions and work of others and acceptance of joint decisions, was generally as good. Schools that have a very good collaboration between principals are $12.67 \%$, those who think are good are $50.70 \%$, those who think are good enough are $30.98 \%$, those who think are not good as much as $4.22 \%$ and those who think are not good as many as $1.40 \%$

The magnitude of the number of schools with the cooperation of principals is quite good at $30.98 \%$ needs to get attention so that it can be improved towards a better. Some of the rights that cause the lack of good cooperation between school principals include the lack of openness in carrying out their duties. The role of the principal in maintaining openness in carrying out tasks is very large. At present many problems that arise in schools are more resolved interpersonal, and do not involve all members to participate in carrying out tasks.
This will cause the role of organizational members to weaken. For certain problems that cannot be solved through mutual consultation and resolved between individuals and should be given the opportunity to argue in accordance with their respective opinions as members of the organization in solving problems.

\section{Job Satisfaction of Educators}

Components of teacher satisfaction according to Herzbergh (1969) said there are several factors that affect job satisfaction and job satisfaction. By Herzbergh these factors are divided into two groups so that this theory is called the two factor theory. The first factor is called motivational factors and the second is called hygiene factors. Motivational factors are factors or situations that are proven as a source of job satisfaction which consists of five parts, namely: (1) achievement, (2) recognition, (3) work itself, (4) responsibility, and ( 5) promotion. While hygiene factors are important factors for motivation in school, these factors do not lead to positive satisfaction in the long run, but if these factors are absent, dissatisfaction arises, which consists of eleven parts namely: (1) salary, (2) possibilities for growth, (3) relationships with subordinates, (4) relationships with colleagues, (5) relationships with superiors, (6) supervision, (7) policy and administration, (8) ) well-known supervision, (9) working conditions, (10) personal life, and (11) job security. Educators who have job satisfaction educators who think that they are very satisfied with their work as much as $5.63 \%$, those who are satisfied as much as $14.08 \%$, those who are quite satisfied as many as $21.12 \%$, those who are less satisfied as many as $33.80 \%$ and those who are dissatisfied as much as $25.35 \%$.

From the results of a descriptive study of educators who chose that they already have Motivation Factors in job satisfaction of educators as much as $54.92 \%$, this proves that motivational factors (motivation factors) can encourage enthusiasm to achieve higher performance and more enable an educator to high-performance rather than satisfying the needs of hygiene factors. Meanwhile, Hygiene 


\section{Johansyah / Journal of Educational Administration Research and Review / \\ Vol. 3 No. 2 December 2019}

Factors in the job satisfaction of educators amounted to $47.88 \%$, this proves that some educators will not encourage the interest of educators to perform well, but if these factors are considered unsatisfactory in various ways such as inadequate salary, unpleasant working conditions, then these factors can be a potential source of dissatisfaction. Although the results are descriptive in this way, the number of educators who are not satisfied with their work in junior high schools in East Borneo is increasing from year to year.

This research on the influence of principals' managerial skills and cooperation of Middle School principals in East Borneo provides evidence that Motivation Factors and Hygiene Factors are not the only factors that lead to job satisfaction of educators, especially East Borneo junior high school educators. Proven managerial managerial skills have an influence of $48.2 \%$, on the satisfaction of educators, while the cooperation of principals has an effect of $42.0 \%$. even jointly the principal's managerial skills and the cooperation of the principals had an effect of $44.0 \%$ on teacher satisfaction.

Robert Kreither said that managers can encourage members of the organization to feel more satisfied with their work. The study measures management in general while this study specifically examines the influence of school managerial skills that have proven to be very effective in influencing the satisfaction of educators.

Based on descriptive analysis, it is seen that $33.80 \%$ of Middle East Middle Eastern teaching staff are not satisfied with having a satisfactory teaching staff satisfaction. To increase the satisfaction of the teaching staff, the principal's managerial skills must be taken seriously as well as the collaboration of the principal. Efforts that can help educators increase the satisfaction of educators are that the principal must set a good example for all educators. Some educators feel there is a conceptual headmaster who is conceptually capable but does not implement the concept properly so that the teaching staff feels they are always required to work optimally as the implementation of the concepts given by the school principal. This situation causes educators to feel burdened and bored with their routine activities.

Another effort that can be done to increase the work satisfaction of educators is to maintain a sense of togetherness among school organizations that is manifested by the existence of values and norms agreed upon by members of the organization and efforts to maintain mutual commitment will foster a sense of satisfaction in the teaching staff themselves. Enforcement of rules by giving rewards to educators who excel and punishes those who violate will be recognized as good coaching and will foster the love of educators for work and school organizations.

\section{CONCLUSION/RECOMENDATION}

Based on the results of research and discussion the following conclusions can be concluded:

1. There is a positive and significant correlation between the principal's managerial skills (X1) and the satisfaction of the teaching staff (Y) of SMPs in East Borneo with a partial correlation coefficient of 0.450 . contribution of principals' managerial skills $(\mathrm{X} 1)$ to teacher satisfaction $(\mathrm{Y})=(0.450) 2 \mathrm{X}$ $100 \%=20.25 \%$.

2. There is a significant correlation between the cooperation of principals (X2) on the satisfaction of teaching staff (Y) SMP in East Borneo with a partial correlation coefficient of $0.209 .2 \times 100 \%=4.36 \%$

3. There is a significant influence of principals' managerial skills (X1) and cooperation of principals (X2) on the satisfaction of educators (Y) SMP in East Borneo with multiple correlation coefficients (Multiple R) of 0.440, which means that the principal's managerial skills ( X1) and the cooperation of school principals (X2) towards the satisfaction of educators (Y) is $44.0 \%$ so that the high and low level of managerial skills in school principals, and the cooperation of school 


\section{Johansyah / Journal of Educational Administration Research and Review / \\ Vol. 3 No. 2 December 2019}

principals will determine the satisfaction of teacher performance.

\section{REFERENCES}

Arikunto,S. 1999. Dasar-Dasar Evaluasi Pendidikan. Jakarta : Bumi Aksara

As'ad, M. 2001. Psikologi Industri.Edisi Keempat. Yogyakarta:Liberty

Benton, D.A. 1996. Applied Human Relation An Organizational Approach. Eaglewood-Cliffs : Prentice Hall

Danim, Sudarman. 2006. Visi Baru Manajemen Sekolah : Dari Unit Birokrasi ke Lembaga Akademik. Jakarta : Bumi Aksara.

Davis, K. Newstrom \& John W. 1996. Perilaku dalam Organisasi : Pendayaan Sumber Daya Manusia. Terjemahan Agus Dharma. Jakarta:Erlangga,

Depdiknas. 2007. Pedoman Penjaminan Mutu Sekolah/Madrasah Bertaraf Internasional Jenjang Pendidikan Dasar dan Menengah (Quality assurance Handbook For Primary and Secondary Level International Standard Schools/Madrasahs). Jakarta: Direktorat Tenaga Kependidikan, Direktorat Jendral Peningkatan Mutu Pendidik dan Tenaga Kependidikan Departemen Pendidikan Nasional,hal.126

Dessler. 1976. Organization and Manajement A Contigence Approach. New York : Practice Hall

Ghozali, I. 2006. Aplikasi Analisis Multivariate dengan SPSS. Semarang : Badan Penerbit Universitas Diponegoro

Gibson, J.L. 1973. Organization Structure: Pracesses Behavior. London : Bussines Publication Inc, page. 137

Handoko, T. Hani. 1993. Manajemen Personalia dan Sumber Daya Manusia. Edisi 2. Yogyakarta : BPFE, hal. 193

Hersey, Paul and Kenneth H. Blanchard. 1977. Manajement of Organization Behavior. New delhi : Printice : Hall ofIndia,Private Ltd.

Herzberg, A. 1969. Management of Organizational Behavior. New Yersey PrenticeHall. Inc

Hidayatun. 2007. Pengaruh Keterampilan Manajerial Kepala sekolah dan Budaya Organisai Terhadap Kepuasan Kerja Guru Madrasah Ibtidaiyah Kecamatan Ungaran Kabupaten Semarang. Tesis Universitas Negeri Semarang.

Higgins,J.M. 1982. Human Relations Concepts and Skills. New York:Random House Publisher

Hoy, C., \& Miskel, G. 1978. Education Administration. New York : Random House Publisher

Kadarman, SJ. Dan Udaya,S. 1996. Pengantar Ilmu Manajemen. Jakarta : Gramedia Pustaka Utama

Koehler, Jerry W. et. al. 1978. Organizational Communication. New York : Holt Rinehart and Winston,Inc
Mangkunegara, A.P. 2001. Manajemen Sumber Daya Manusia Perusahaan. Bandung : PT. Remaja Rosdakarya, hal.120

Manullang, B. 1985. Pengambilan Keputusan Parstisipatif, Komunikasi Persuasif, dan Kerjasama Guru dengan Kepala Sekolah. (disertasi), .Jakarta : FPS IKIPJakarta

Megginson, L.C., Mosley,D.C., and Pietri,P.H, 1992. Management : Concept and Application. New York : Harper Collins Publisher. Page 30

Milton, Charles R. 1981. Human Behavior in Organization Three Levels of Behavior. New Jersey Engliwood cliff : Printice Hall Inc

Mulyasa, E. 2004. Manajemen Berbasis Sekolah, Konsep, Strategi, Implementasi. Per Collins Publisher Bandung : Rosdakarya

Owen, Robert G. 1991. Organizational Behavior in Education. Massacussets:Allyn and Bacon

Permendiknas No. 13 Tahun 2007 tentang Standar Kepala Sekolah/Madrasah.

Rais, H.M. 2014. Pengaruh Kemampuan Manajerial dan Kerjasama Kepala Sekolah Terhadap Kinerja Pendidik SMP Negeri 1 Bontang. Tesis Program Pascasarjana Kependidikan Universitas Mulawarman: Samarinda

Robbins, D. Stephen. 2003. Perilaku Organisasi. Jakarta: Gramedia

Robbins, S.P. 1998. Organizational Behavior. Englewood Cliffs, New Jersey: Prentice Hall, Inc. Page. 139

Sergiovanni, T.J \& Carver, F.D., 1980. The New School Executive : A Theory of Administration ( $\left.2^{\text {nd }} E d\right)$. New York. Happer \& Row Publisher

Sergiovani, T.J, Burligame, M., Coombs, F.S., \& Thurston,P.W., 1992. Educational Governance and Administration ( $3^{\text {rd }} \mathrm{Ed}$ ). Boston: Allyn and Bacon

Steers, Richard M. 1980. Efektifitas Organisasi(Terjemahan). Jakarta : Erlangga

Stoner, A.F. 1988. Manajemen. Alih Bahasa oleh Bakowatun, Wihelmus W. Jakarta : Midas Surya Grafindo

Stoner, James A.F. 1970. Manajemen. London : Prentice Hall International Inc, Page.331

Syahril, 1994. Kontribusi Persepsi Guru Mengenai Iklim Kerjasama di Sekolah Terhadap Prestasi Kerja Guru. Laporan Penelitian IKIP Padang

Sugiyono. 2003. Statistik Untuk Penelitian. Bandung : CV Alfabeta. Hal.72

Thoha Miftah, kepemimpinan dalam manajemen suatu pendekatan prilaku. Edisi ke-1. Cet.ke-6 (Jakarta :PT. Grafindo Persada, 1995, h.68)

Ubben, G.C., Hugges, L.W. 1992. The Principal, Creative Leadership for Effective. Boston : Allyn and Bacon

Wahjosumidjo. 1984. Kepemimpinan dan Motivasi. Jakarta : Ghalia Indonesia

Wahjosumidjo. 2000. Kepemimpinan Kepala Sekolah. Jakarta : Raja Grafindo Persada. Hal. 101

Wiles,Kimball, John. 1961. Supervision for Better School. New York : Prentice Hall,hal 18-25 
Winardi, D. 1996. The Meaning of Supervision. Jakarta:IATVEP.B, hal:11

Yulk, G.A. 1998. Kepemimpinan dalam Organisasi. Terjemahan oleh Yusuf Udaya. Jakarta:Prenhalindo 